\title{
Burial-induced deterioration in leather: a FTIR-ATR, DSC, TG/DTG, MHT and SEM study
}

\author{
Gabriela Vyskočilová', Cristina Carşote ${ }^{2}$, Richard Ševčík ${ }^{1}$ and Elena Badea ${ }^{3,4^{*}}$ [D
}

\begin{abstract}
In this study we used an analytical approach based on complementary techniques that targets all structural levels of collagen in leather to investigate how vegetable-tanned leather deteriorates during soil burial tests. For the first time, a group of deterioration markers specific to molecular, fibrillar and fibrous structure of collagen in leather was associated with the deterioration of buried leather. The application of the second order derivative of FTIR-ATR spectra analysis allowed us to detect loosening of collagen-tannin matrix, de-tanning and gelatin formation based on the behaviour of collagen and tannin spectral components (intensity variation and shifts). Collagen denaturation observed by DSC analysis and its thermo-oxidative behaviour measured by TG/DTG analysis, as well as the altered morphology of collagen (namely melt-like fibres and distorted fibrillar ultrastructure) imaged by SEM confirmed the FTIR-ATR analyis results. These analytical outcomes enabled us to understand the effect of leather hardening/cementing through soil mineral penetration into its fibrous structure and thus correctly interprete the higher-than-expected shrinkage temperatures and intervals determinatd by MHT method. Thus, MHT method proved to be suitable for a quick evaluation method that can direcly support the first conservation decision after excavation. The combination of FTIR-ATR, DSC, TG/DTG and SEM can be particularly useful to provide insights on the deterioration mechanism of archaeological leather and support best decision on its long-term preservation.
\end{abstract}

Keywords: Vegetable tanned leather, Soil burial, Deterioration, FTIR-ATR, DSC, TG/DTG, SEM, MHT

\section{Introduction}

Materials, whether natural or created by humans, sooner or later undergoes alterations as a consequence of the interaction between their structure and environment. Leather can be considered as the first biomaterial ever produced. It was one of the major materials in the past, and its use continues into the present. Its wide usability is the reason why leather artefacts are frequently found during archaeological excavations. The varied properties of leather that provide such a wide use are due to the intrinsic chemical, morphological and physical properties of collagen, hence to the species from which it originates, and to the method with which hide was processed. The

\footnotetext{
*Correspondence: elena.badea@unito.it

${ }^{3}$ Advanced Research for Cultural Heritage Group (ARCH Lab), National Research \& Development Institute for Textile and Leather, ICPI Division, Bucharest, Romania

Full list of author information is available at the end of the article
}

vital characteristics of collagen as the main structural protein of most hard and soft tissues in animals and the human body, including thermal stability, mechanical strength and the ability to engage in specific interactions with other biomolecules, lies on its hierarchical structure based on the collagen fibril as an elementary building block [1]. A collagen fibril is a bundle of collagen molecules of approximately 10 to $300 \mathrm{~nm}$ in diameter and several micrometres in length. A collagen molecule is composed of three left-handed helical chains, which assemble to form a triple-helix structure [2-5]. This triple helix, coiled structure is stereo-dynamically favourable to allow strands to be interwoven together and assemble by way of cross-linking in a complex, in a hierarchical manner that ultimately leads to the macroscopic fibres that form extensive and robust networks, providing the dermis with strength, firmness and elasticity. A collagen fibre essentially comprises bundles of smaller fibrils and

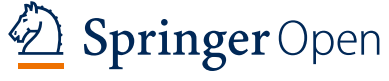

(c) The Author(s) 2022 Open Access This article is licensed under a Creative Commons Attribution 4.0 International License, which permits use, sharing, adaptation, distribution and reproduction in any medium or format, as long as you give appropriate credit to the original author(s) and the source, provide a link to the Creative Commons licence, and indicate if changes were made. The images or other third party material in this article are included in the article's Creative Commons licence, unless indicated otherwise in a credit line to the material. If material is not included in the article's Creative Commons licence and your intended use is not permitted by statutory regulation or exceeds the permitted use, you will need to obtain permission directly from the copyright holder. To view a copy of this licence, visit http://creativecommons.org/licenses/by/4.0/. The Creative Commons Public Domain Dedication waiver (http://creativeco mmons.org/publicdomain/zero/1.0/) applies to the data made available in this article, unless otherwise stated in a credit line to the data. 
has a characteristic coiled structure [6]. Through tanning (namely collagen binding with tanning agents), mechanical strength and thermal stability of skins and hides are enhanced allowing their conversion into a durable and manageable material called leather which does not rot in moist condition and withstand wear and tear. Such properties have allowed leather to survive even under extreme condition such as arid waterless areas, waterlogged areas, permafrost, peat bogs etc.

Leather making is a very long process and consists of many different chemical and mechanical process steps [7]. Tanning is the most important step of the whole leather making process. It is commonly performed either by vegetable or mineral tanning. Vegetable tannage with organic materials obtained from different parts of plants including woods, barks, fruits, fruit pods, seeds and leaves left to macerate in water was mostly used up to nineteenth century. Current commercial tanning agents, include mostly mineral (mainly $\mathrm{Cr}$ (III) salts) and organic (aldehydes) reagents, while vegetable tannins (polyphenolic tannins) are used for luxury leather [8]. Each of these tannages have different chemistries, vegetable tanning being the least well understood [9]. The most recent tanning theory proposed by Covington [10] is based on the link-lock concept that requires an initial reaction to link the collagen into the surrounding matrix of water and a second reaction component to lock the linked structure together, creating a supramacromolecular structure around the triple helices. According to Covington, only the primary link reaction occurs between plant polyphenols and collagen through multiple hydrogen bonding and some covalent bonding via quinoid species, at the collagen lysine amino group. However, a further stabilisation of the collagen matrix is provided by the substitution of some of the supramolecular water (i.e. dehydration) and interaction of tannins with some of the remaining water.

Although vegetable-tanned leather is a highly durable material, its integrity is influenced by external factors which may alter its physical, chemical and mechanical properties. Yet, physical and chemical properties, but also the aesthetic appeal of leather, gradually deteriorate as a result of interaction with its environment until the loss of the function of the object or even until its total loss. In the case of archaeological leather recoverd from underground, the kinetics of deterioration may also be influenced by the sudden change of the environmental conditions through exposure to the atmosphere. It is known that during burial, most objects will experience a period of rapid and extensive degradation initially followed by a longer period in which the object nearly reaches equilibrium with its environment, then deterioration gradually slows down until the moment of excavation, when exposure to a new environment accelerates the process again [11]. The archaeological leather damage condition should therefore be evaluated with utmost urgency to define the optimal conservation conditions and prioritize possible conservation interventions. However, the few studies on archaeological leather reported so far are dealing with the origin of neolithic leather by microstructural, chemical and isotopic evidence [12], identification of archaeological leather by mass spectrometry (ZooMS) [13], evaluation of archaeological leather through amino acid composition and thermal analysis [14], red stain degradation [15] or linseed oil emulsion used in dressing archaeological leather [16]. On the other hand, some of us have used multitechnical approaches to characterize historical leathers which may be composed from a heterogeneous mixture of tanned collagen (chemically modified collagen showing a leather-like hytdrothermal behaviour), un-tanned collagen (chemically unmodified collagen showing a parchment-like behaviour), gelatinised and amorphous collagen, and deterioration compounds [17-20].

To facilitate the application of a multi-analytical approach to the study of leather remains which spent prolonged periods of time within the earth, burial tests were performed on newly produced leather from both bovine and ovine hides tanned with bydrolisable and condensed tannins. A combination of techniques such as Fourier transform infrared spectroscopy in attenuated total reflection mode (FTIR-ATR), thermal microscopy (MHT method), differential scanning calorimetry (DSC), thermogravimetry (TG/DTG) and scanning electron microscopy (SEM) was employed to provide the best possible insight into the deterioration pattern of burried leather with special focus on collagen-tannin matrix detanning and collagen gelatinisation. This approach targets different structural levels of collagen, from molecules to fibrils and fibres, while bringing the advantage of combining surface and bulk analyses.

\section{Materials and methods Materials}

Four newly manufactured vegetable tanned leathers purchased from the Gara TZL PLUS s.r.o., Otrokovice, Czech Republic were used to perform the burial tests. The possible influence of the animal species (bovine and sheep) and age (calf and cattle) as well as of the tannin type (hydrolysable and condensed) was considered. In Table 1, the symbols of the investigated leather samples are explained: the first letter refers to animal species ( $\mathrm{C}$ for calf, $\mathrm{Ca}$ for cattle and $\mathrm{S}$ for sheep), the second one to the tannin type ( $\mathrm{C}$ for condensed tannin and $\mathrm{H}$ for hydrolysable tannin) while the figure 
Table 1 List of the buried leather samples, with their symbols, animal origin and burial time

\begin{tabular}{llll}
\hline Animal species & Tannin type & $\begin{array}{l}\text { Burial time } \\
\text { (years) }\end{array}$ & Symbol \\
\hline Calf & Hydrolysable & 0 & $\mathrm{CH} 0$ \\
& & 1 & $\mathrm{CH} 1$ \\
& & 2 & $\mathrm{CH} 2$ \\
Calf & Condensed & 0 & $\mathrm{CC} 0$ \\
& & 1 & $\mathrm{CC} 1$ \\
& & 2 & $\mathrm{CC} 2$ \\
Sheep & Condensed & 0 & $\mathrm{SC} 0$ \\
& & 1 & $\mathrm{SC} 1$ \\
& & 2 & $\mathrm{SC} 2$ \\
Cattle & & 0 & $\mathrm{CaC} 0$ \\
& & 1 & $\mathrm{CaC} 1$ \\
& & 2 & $\mathrm{CaC} 2$ \\
& & 4 & $\mathrm{CaC} 4$ \\
\hline
\end{tabular}

represents the burial time ( 0 for not-buried samples, 1 , 2 or 4 for samples buried for 1-year, 2-year and 4-year periods).

Leather samples were buried to $50 \mathrm{~cm}$ depth, at $454 \mathrm{~m}$ altitude, in the western part of Czech Republic, a region characterised by the mild central-European climate [21]. The average annual temperature is $(6.6-8.0){ }^{\circ} \mathrm{C}$ and the average rainfall per year is (550-650) $\mathrm{mm}$ [22]. The soil has a sandy loam structure and neutral pH around 6.5. Sandy loam is a welldrained soil mostly composed of sand (silicon dioxide and calcium carbonate) and clay (hydrous aluminium phyllosilicate minerals). Leather is best preserved in very wet, very dry, frozen or low-oxygen burial environments which protect it against biological activity. On the other hand, leather is poorly preserved on sites where there are seasonal freeze-thaw cycles, the soil is well-drained and oxygenated. The $\mathrm{pH}$ of the burial environment will also influence the preservation of leather, a material produced with a $\mathrm{pH}$ of about 4.5 to 5.5 to ensure the fats and tannins remain bound in the leather structure. Hence, the soil and climate conditions of our experiments should rapidly degrade the buried samples. The samples were dug up and analysed after 1 - and 2-year burial periods. Only the cattle sample was kept buried for a 4-year period. Before performing the analytical measurements, all leather samples were soft brushed and rinsed with jets of deionised water to remove the ingrained soil remains, and dried at room temperature $\left(21 \pm 1{ }^{\circ} \mathrm{C}, 45 \pm 5 \% \mathrm{RH}\right)$ under light pressure to avoid wrinkling.

\section{Methods}

Fourier transform infrared spectroscopy in attenuated total reflection mode (FTIR-ATR)

FTIR-ATR measurements were carried out using an ALPHA FTIR (Bruker Optics, Germany) equipped with a Platinum ATR module. The penetration depth, depending on the wavelength, the refractive indices of ATR crystal typically amount to a few microns (ca. 0.5-3 $\mu \mathrm{m}$ ). Spectra were recorded by co-adding of 64 scans in the range from 4000 to $400 \mathrm{~cm}^{-1}$ with a spectral resolution of $4 \mathrm{~cm}^{-1}$. Six diferent replicates were measured on both sides of each sample and averaged before data preprocessing. Opus 7.0 software (Bruker Optics, Germany) was used for the acquisition and processing of the spectra, while their graphic presentation was done with Origin 7.5 software.

\section{Differential scanning calorimetry (DSC)}

DSC measurements were performed with a DSC 204 F1 Phoenix instrument (Netzsch, Germany) in nitrogen flow $(20 \mathrm{~mL} / \mathrm{min})$, in the temperature range $(25-280){ }^{\circ} \mathrm{C}$ at a scanning rate of $10 \mathrm{~K} / \mathrm{min}$, in open aluminium crucibles as previously described [23]. Three measurements were performed using fresh subsamples of about $5 \mathrm{mg}$ for each leather sample.

\section{Thermogravimetry/differential thermogravimetry (TG/DTG)}

TG/DTG curves were obtained using a STA 449 C Jupiter instrument (Netzsch, Germany). Leather samples of about $5 \mathrm{mg}$ were heated in open aluminium pans in the temperature range $(25-500){ }^{\circ} \mathrm{C}$ in nitrogen flow $(100 \mathrm{~mL} /$ $\mathrm{min})$, at a scanning rate of $10 \mathrm{~K} / \mathrm{min}$. The rate $\mathrm{v}_{310}$ $(\mathrm{d} \% \Delta \mathrm{m} / \mathrm{dt})$ of the first process of thermo-oxidation was calculated at $310{ }^{\circ} \mathrm{C}$ from the first derivative of TG curve (DTG curve) [23].

\section{Micro Hot Table (MHT)}

MHT measurements were carried out using a homemade MHT equipment consisting of a micro-heating plate (Caloris Group, Romania) controlled by a temperature processor and a stereomicroscope (Leica S4E) assisted by a homemade software F.L.T.K. 1.1.X. for data collection. Samples composed of a few fibres from each side of a leather sample were wetted with demineralised water and kept for $10 \mathrm{~min}$ on a microscope slide with concavity to facilitate fibres' separation. Well separated fibres were then covered with a slide, placed on the heating table and heated at $2 \mathrm{C} / \mathrm{min}$. Their shrinkage activity was observed at $40 \times$ magnification. At least two measurements were made for each sample. 


\section{Scanning electron microscopy (SEM)}

Examination of the leather surface morphology before and after the soil burial tests was performed using a Tescan MIRA3 (Brno, CZ) scanning electron microscope. Samples mounted on carbon stubs and covered by a $20 \mathrm{~nm}$ AuPd (80/20) layer were observed at different locations at increasing magnification (from 500 to $50,000 \times$ ). Only the grain surface of leather samples was AuPd covered. SEM observation was performed at $15 \mathrm{keV}$ accelerating voltage and $15 \mathrm{~mm}$ working distance.

\section{pH measurement}

Surface $\mathrm{pH}$ measurements were carried out according to the ISO 10390 standard [24] using a surface electrode WTW SenTix Sur and a pHmeter Mettler Toledo SevenCompact S220. Each measurement spot $\left(1 \times 1 \mathrm{~cm}^{2}\right)$ was damped with a droplet of water using a pipette. After 3 min extraction, the electrode was placed on the spot surface and the $\mathrm{pH}$ of the water film was measured. The $\mathrm{pH}$ value was obtained as the average between 3 measurements.

\section{Results and discussion}

\section{Effects of leather burial on collagen shrinkage activity} by MHT method

It was shown that the hydrothermal stability of new, undamaged leather depends on the tannin type, animal species and processing method, and influences leather resistance against deterioration [24-27]. However, both the effect of animal species and tannin type levels out as the damage progresses and hydrothermal stability becomes increasingly influenced by the mechanism of deterioration. The MHT method was purposely set up for quick and simple evaluation of the hydrothermal stability of historical leather and parchment using very tinny sample. It combines thermal treatment and stereomicroscopy [28] allowing conservators to visualise how collagen fibres contract on heating using an inexpensive equipment, easy to use and providing apparently easy to interpret results [29]. The shrinkage (contraction) activity of collagen fibres is described by a sequence of temperature intervals: no activity-A1-B1$\Delta \mathrm{C}-\mathrm{B} 2-\mathrm{A} 2-$ complete shrinkage. Interval $\mathrm{A}$ is characterized by shrinkage activity in individual fibers, one fibre at a time and with pause in between the individual movements. When shrinkage activity in one fibre is immediately followed by shrinkage activity in another fibre without pause, interval $\mathrm{B}$ is reached. Interval $\Delta C$, known as the main shrinkage interval, is defined by the simultaneously and continuously shrinking of at least two fibres. Shrinkage temperature $T_{\mathrm{s}}$ refers to the starting temperature of the main shrinkage interval, while
$T_{\text {first }}$ and $T_{\text {last }}$ are defined as the temperatures at which the first and last shrinkage activity of an individual fiber is observed. The total length of the shrinkage process is expressed as $\Delta T=\left(T_{\text {last }}-T_{\text {first }}\right)$.

In the last two decades, shrinkage temperature has been widely used as a metric for damage in old leather and parchment [23, 30-33] as well as to study the effects of various ageing or conservation treatments on leather and parchment [34-38]. Some of us have reported how leather hydrothermal stability, expressed as $T_{\mathrm{f}}$ and $T_{\mathrm{s}}$, and structural cohesivity and heterogeneity, expressed as $\Delta C$ and $\Delta T$, respectively, correlates with natural or artificially induced ageing patterns $[18$, $25,33]$.

For the investigated vegetable tanned leathers, the variation of shrinkage parameters with burial times is reported in Fig. 1 where the cumulated $(\mathrm{A} 1+\mathrm{B} 1)$ and $(\mathrm{A} 2+\mathrm{B} 2)$ intervals are illustrated. The most important changes we observed were the following:

i. $T_{\mathrm{s}}$ increased for all leather samples, regardless of the type of tannin (hydrolysable or condensed), animal species (calf or sheep) or age (calf and cattle) and duration of treatment, except for the $\mathrm{CaC} 4$ sample which no longer shows contraction activity in the main shrinkage interval $\Delta \mathrm{C}$.

ii. $T_{\mathrm{f}}$ decreased for all samples, except for SC2. A dramatic decrease occurred for the $\mathrm{CH}$ leather samples tanned with hydrolysable tannin.

iii. The shrinkage interval $\Delta C$ generally increased, except for the $\mathrm{CaC} 4$ sample.

iv. The total shrinkage interval $\Delta T$ generally increased as a result of increasing either $(\mathrm{A} 1+\mathrm{B} 1)$ or $(\mathrm{A} 2+\mathrm{B} 2)$ or both intervals.

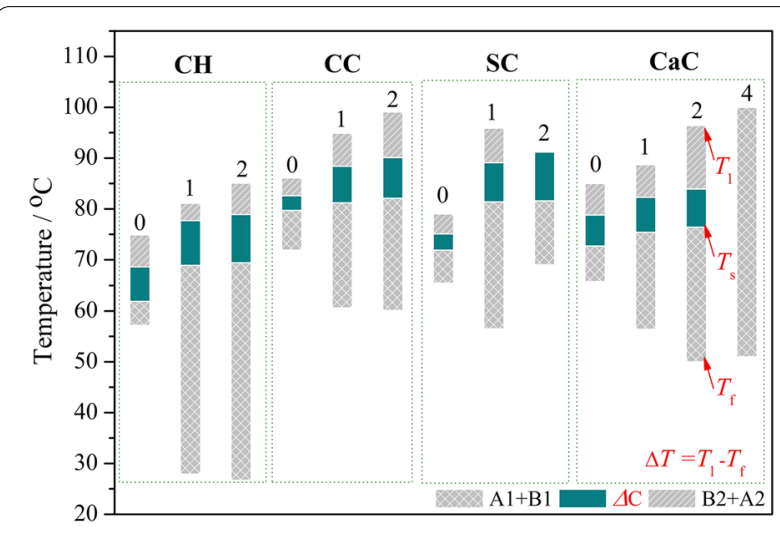

Fig. 1 Stacked column charts displaying the shrinking intervals for collagen fibres for the investigated leathers before and after the soil burial tests. The main shrinkage temperatures $\left(T_{f} T_{s}\right.$ and $\left.T_{f}\right)$ and intervals $(\Delta C$ and $\Delta T)$ are indicated 


\section{v. The shrinkage interval $\Delta C$ disappears for $\mathrm{CaC}$.}

The most important change refers to an increase in the degree of leather structural inhomogeneity. The increase in structural inhomogeneity was correlated to the keysteps of leather deterioration: thermal destabilization of chemically modified collagen (collagen-tannin matrix), de-tanning (breakdown of the interactions between collagen and tannin), thermal destabilization of chemically unmodified collagen (de-tanned collagen) and gelatinization [18]. Thus, the length of $(\mathrm{A} 1+\mathrm{B} 1)$ interval was related with formation of pre-gelatinized collagen and gelatin, while de-tanning was associated to the length of (A2+B2) interval [18]. For example, in the case of CH1 and $\mathrm{CH} 2$ leather samples, $T_{\mathrm{f}}$ sharply decreases below $30{ }^{\circ} \mathrm{C}$ causing the $(\mathrm{A} 1+\mathrm{B} 1)$ interval lengthening. This could be explained by thermal destabilisation and gelatinisation of collagen microfibres [18, 25, 39] and attributed to the neutral soil $\mathrm{pH}$ and humidity which favour de-tanning process. It is known that vegetable tannin fixation on collagen is at minimum at $\mathrm{pH} 5$ and decreases with $\mathrm{pH}$ increasing. Once the bonds between collagen and tannin are broken, collagen hydrolyses is promoted by soil moisture, while tannins and their possible degradation compounds are washed out by rainwater. On the other hand, de-tanning is in contrast the $T_{\mathrm{s}}$ increase measured for $\mathrm{CH}$ samples, from $62{ }^{\circ} \mathrm{C}$ to around $70{ }^{\circ} \mathrm{C}$. In general, thermal stabilisation is related to a stronger attraction between the collagen fibres that makes the fibrous network more cohesive (indicated by a shorter $\Delta \mathrm{C}$ interval) and less susceptible to gelatinisation.

In the case of $\mathrm{CC} 1$ and $\mathrm{CC} 2$ leather samples, the increase of structural inhomogeneity is equally due to the increase in the number of collagen fibres showing discrete shrinkage of individual fibres in both $(\mathrm{A} 1+\mathrm{B} 1)$ and $(\mathrm{A} 2+\mathrm{B} 2)$ intervals. $T_{\mathrm{f}}$ values higher than $60^{\circ} \mathrm{C}$ preclude the existence of gelatin and pregelatinized collagen fractions. On the other hand, the increase of $(\mathrm{A} 2+\mathrm{B} 2)$ interval might be attributed to collagen de-tanning and formation of multiple collagen-tannin fractions with distinct tanning degree and distinct thermal stability.

$\mathrm{CaC} 1$ and $\mathrm{CaC} 2$ leather samples behaves similarly to $\mathrm{CC} 1$ and $\mathrm{CC} 2$, respectively. SC1 leather sample behaves similarly to $\mathrm{CC} 1$, too, while the SC2's behaviour is clearly different in that the $(\mathrm{A} 2+\mathrm{B} 2)$ interval fully disappears. A more rapid thermal destabilisation of the collagen-tannin matrix within sheep leather and a greater propensity to de-tanning during artificial ageing compared to calf leather has already been observed by some of us [25, 39].

Interestingly, for all leather samples, the more coherent collagen fibres (namely those showing shrinkage in the main shrinkage interval $\Delta C$ ) shown a slight increase of their thermal stability (indicated by the $T_{\mathrm{s}}$ increase), while the length of $\Delta \mathrm{C}$ interval increased. This behaviour is in contrast to what Larsen et al. [29] and Carsote and Badea [18] observed for most artificially aged and historical leathers, namely a parallel decrease of $T_{\mathrm{s}}$ value and $\Delta C$ length as deterioration increases. On the other hand, a parallel increase of $T_{\mathrm{s}}$ and $\Delta C$ interval was recently reported for vegetable tanned leather exposed to low-dose gamma irradiation and explained by the formation of molecular cross-links that draws the collagen molecules and fibrils closer together, thus increasing their structural order and thermal stability [40]. In the case of buried leathers, we could infer a mechanical strengthening of collagen fibres through the cementation effect of soil minerals, especially silica, instead of a chemical strengthening (cross-linking), with similar effects on leather shrinkage temperature $T_{\mathrm{s}}$ and $\Delta \mathrm{C}$ interval. Consequently, the extension of $(\mathrm{A} 1+\mathrm{B} 1)$ and $(\mathrm{A} 2+\mathrm{B} 2)$ intervals should also be partially ascribed to the slowdown of the contraction movements caused by "hardening and welding" of collagen fibres and silica minerals.

Finally, the $\Delta C$ disappearance, as for $\mathrm{CaC} 4$ sample, has been related to a major damage, i.e., the conversion of collagen ordered structures into coiled structures [38, 39].

\section{Effects of leather burial on collagen thermal stability by DSC}

The DSC curves for the new leather samples measured in open crucibles and gas flow (Fig. 2) displayed a broad endotherm ranging from room temperature to about $120^{\circ} \mathrm{C}$, associated with loss of moisture, followed by two small endotherms in the temperature intervals (135150) ${ }^{\circ} \mathrm{C}$ and $(220-240){ }^{\circ} \mathrm{C}$, respectively (Table 2). These two small endotherms are in good agreement with the literature data [41-43] and our previous results $[44,45]$. Budrugeac et al. [17] assigned these two endotherms to thermal denaturation of the crystalline collagen embedded in the amorphous matrix. Considering the very different thermal stability of the two collagen populations, we attribute the two endotherms to two collagen populations with distinct crystallinity and hydration degree according to the two-phase model of collagen in leather represented by a crystalline phase embedded into an amorphous matrix [43].

For all buried samples, these small endotherms disappeared after 1-year underground. A similar behaviour, previously observed for parchments exposed to the combined action of polluting gases $\left(50 \mathrm{ppm} \mathrm{NO}+\mathrm{NO}_{2}\right)$ and dry heat $\left(100{ }^{\circ} \mathrm{C}\right)$, was attributed to the full denaturation of both the amorphous and crystalline collagen fractions [45]. This indicates that he burial tests we performed had already a strong denaturing effect on collagen after the first year regardless of the type of tannin or animal 

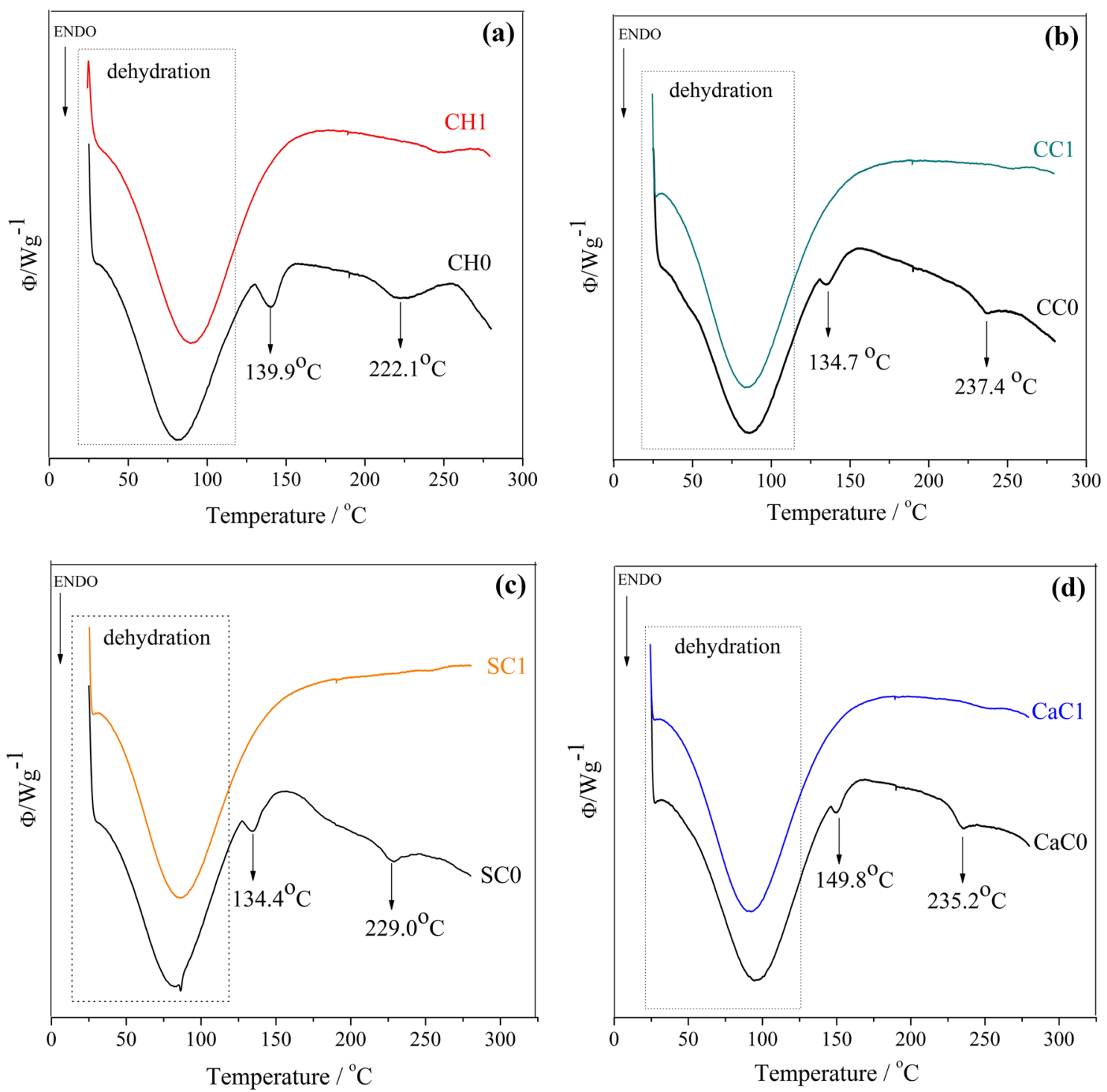

Fig. 2 DSC curves obtained in open crucibles and nitrogen flow for leather samples before and after the 1-year soil burial: a CH; b CC; c SC and $\mathbf{d}$ $\mathrm{CaC}$. The dehydration peak, denaturation peak of the collagen-tannin matrix (showing a maximum at $T_{\mathrm{d} 1}$ ), and denaturation peak of the crystalline fraction (showing a maximum at $T_{\mathrm{d} 2}$ ) are indicated

species. The DSC results thus confirm that the increased thermal stability determined by MHT method is not real and can only be explained by the mechanical effect of fiber aggregation through soil minerals.

\section{Effects of leather burial on collagen susceptibility to thermo-oxidative deterioration by TG/DTG}

It was reported that the non-isothermal deterioration of leather occurs through three processes accompanied by mass loss: (i) water loss at $T<150{ }^{\circ} \mathrm{C}$, (ii) pyrolytic thermo-oxidation and (iii) thermal decomposition of the material $[17,23]$. These processes are evidenced in the DTG curves by the peaks I, II and III (Fig. 3). The rate of the thermo-oxidation process corresponds to the maximum of the thermo-oxidation peak, namely the peak II (Fig. 3). For various collagenbased materials it was shown that the rate $\mathrm{d} \% \Delta \mathrm{m} / \mathrm{dt}$ of the pyrolytic thermo-oxidation process calculated at $310{ }^{\circ} \mathrm{C}$ well correlates with the collagen matrix crosslinking degree. Accordingly, Budrugeac et al. [17] used this parameter as an indicator of the damage level in historical collagen-based materials relating the high rates of the thermo-oxidation process to not-damaged/ well conserved leather, and the lower rates to various 
Table 2 DSC and TG/DTG parameters of leather samples before and after the soil burial tests: denaturation temperature of the collagen matrix $\left(T_{\mathrm{d} 1}\right)$, denaturation temperature of the crystalline fraction $\left(T_{\mathrm{d} 2}\right)$ and the rate $\left(V_{310} / \% \mathrm{~min}^{-1}\right)$ of the first process of thermal oxidation

\begin{tabular}{|c|c|c|c|}
\hline \multirow{2}{*}{$\begin{array}{l}\text { Method } \\
\text { Sample }\end{array}$} & \multicolumn{2}{|l|}{ DSC } & \multirow{2}{*}{$\begin{array}{l}\text { TG/DTG } \\
\mathrm{V}_{310} / \% \mathrm{~min}^{-1}\end{array}$} \\
\hline & $\begin{array}{l}T_{\mathrm{d} 1}\left({ }^{\circ} \mathrm{C}\right) \\
\text { Collagen-tannin } \\
\text { matrix }\end{array}$ & $\begin{array}{l}T_{\mathrm{d} 2}\left({ }^{\circ} \mathrm{C}\right) \\
\text { Crystalline } \\
\text { collagen }\end{array}$ & \\
\hline $\mathrm{CHO}$ & 139.9 & 222.1 & 4.24 \\
\hline $\mathrm{CH} 1$ & - & - & 3.76 \\
\hline $\mathrm{CH}_{2}$ & - & - & 3.40 \\
\hline $\mathrm{CCO}$ & 134.7 & 237.4 & 3.96 \\
\hline $\mathrm{CC} 1$ & - & - & 2.52 \\
\hline $\mathrm{CC} 2$ & - & - & 1.90 \\
\hline SCO & 134.4 & 229.0 & 4.05 \\
\hline $\mathrm{SC} 1$ & - & - & 2.75 \\
\hline SC2 & - & - & 2.53 \\
\hline $\mathrm{CaCO}$ & 149.8 & 235.2 & 4.85 \\
\hline $\mathrm{CaC} 1$ & - & - & 3.49 \\
\hline $\mathrm{CaC} 2$ & - & - & 3.12 \\
\hline $\mathrm{CaC} 4$ & - & - & 2.52 \\
\hline
\end{tabular}

damage levels. In fact, the lower the rate the higher the deterioration degree. The rates $\mathrm{d} \% \Delta \mathrm{m} / \mathrm{dt}$ of the pyrolytic thermo-oxidation process for the investigated leather samples reported in Table 2 show a progressive decrease of the oxidation rate as burial time increases. This trend of the thermo-oxidation susceptibility clearly indicates an increase of the damage level with burial time.
Effects of leather burial on molecular alteration of collagen-tannin matrix by FTIR-ATR

FTIR spectroscopic analysis is widely used to characterise the molecular changes in the collagen secondary structure [46-51]. Due to its non-invasivity and nondestructivity, FTIR-ATR technique has proved suitable for studying the alterations in the secondary structure of collagen within historical leathers $[20,52]$ as well as for characterizing their vegetable tannin composition [53, 54]. The following aspects were considered when studying the FTIR-ATR spectra of the investigated leather samples: (i) the effects of burial tests on the complex spectral bands of leather characterised by the overlapping of collagen (amide I and amide II) and vegetable tannin bands; (ii) the identification of other compounds on the leather surface, due to either the fabrication process or burial test.

In Fig. 4, the FTIR-ATR spectra of the buried leather samples, $\mathrm{CaC} 1, \mathrm{CaC} 2$ and $\mathrm{CaC} 4$, are illustrated and compared with that of the new leather $\mathrm{CaC} 0$. For all leather samples, the main infrared absorption bands of collagen were cleary detected and attributed: (i) the amide A (AA) at $\sim 3300 \mathrm{~cm}^{-1}$ related to stretching vibrations of the amide $\mathrm{N}-\mathrm{H}$ bonds; (ii) the amide $\mathrm{B}\left(\mathrm{A}_{\mathrm{B}}\right)$ at $\sim 3080 \mathrm{~cm}^{-1}$ attributed to the Fermi resonance overtone of the amide II vibration; (iii) the amide $\mathrm{I}\left(\mathrm{A}_{\mathrm{I}}\right)$ at $\sim 1633 \mathrm{~cm}^{-1}$ arising mainly from the $\mathrm{C}=\mathrm{O}$ stretching vibration; (iv) the amide II $\left(\mathrm{A}_{\mathrm{II}}\right)$ at $\sim 1538 \mathrm{~cm}^{-1}$ attributed to $\mathrm{NH}$ in plane bend and $\mathrm{CN}$ stretching vibration and $(\mathrm{v})$ amide III $\left(\mathrm{A}_{\text {III }}\right)$ at $\sim 1235 \mathrm{~cm}^{-1}$ corresponding to the $\mathrm{NH}$ bending, $\mathrm{CN}$ stretching vibration and small contributions from both $\mathrm{CO}$ in plane bending and $\mathrm{CC}$ stretching vibration. The presence of lipids typical bands at $\sim 2920$ and $2850 \mathrm{~cm}^{-1}$ $\left(v^{\text {as }}{ }_{\mathrm{CH} 2}\right.$ and $\left.v^{\mathrm{s}}{ }_{\mathrm{CH} 2}\right)$ and at $\sim 1735\left(v^{\mathrm{as}}{ }_{\mathrm{C}=\mathrm{O}}\right)$ could be ascribed to the fatliquoring products used in the leather finishing

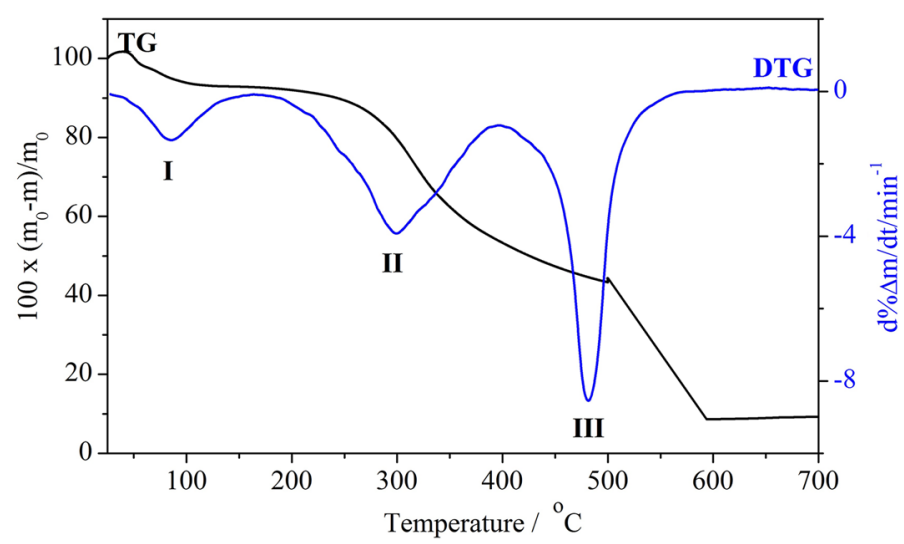

Fig. 3 TG and DTG curves showing the typical decomposition pattern for a newly manufactured vegetable-tanned leather characterised by three successive exothermic processes: water loss (peak I), pyrolytic thermal oxidation (peak II) and thermal decomposition (peak III) 


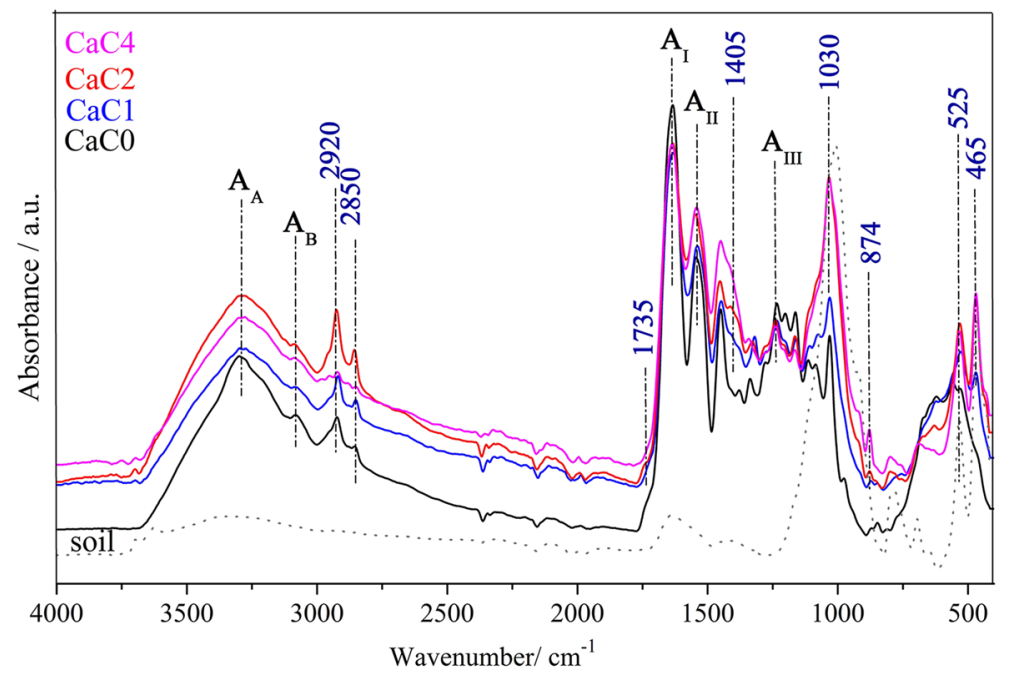

Fig. 4 FTIR-ATR spectra for $C a C$, before and after the soil burial tests. The main absorption bands of collagen $\left(A_{A}, A_{B}, A_{1}, A_{\|}\right.$and $\left.A_{\| 1}\right)$, as well as those corresponding to calcium carbonate $\left(1405\right.$ and $\left.874 \mathrm{~cm}^{-1}\right)$, fatliquoring oils/fats $\left(2920,2850\right.$ and $\left.1735 \mathrm{~cm}^{-1}\right)$ and aluminosilicates $(1030,525$ and $465 \mathrm{~cm}^{-1}$ ) are highlighted

process to impart softness and flexibility to leather. Worthy of note, these bands show a significant intensity reduction in the $\mathrm{CaC} 4$ spectrum indicating the loss of fatliquoring oils which are water-soluble and susceptible to oxidation. Oils leaching makes leather more vulnerable to hydrolysis and to losing its collagenous ordered structure. This finding well correlates with the lack of the main shrinking interval in case of $\mathrm{CaC} 4$ sample. Soiling effects are indicated by the aluminosilicates specific bands at $\sim 1030 \mathrm{~cm}^{-1}\left(v_{\mathrm{Si}-\mathrm{O}}\right), 525\left(\delta_{\mathrm{Al}-\mathrm{O}-\mathrm{Si}}\right)$ and $465 \mathrm{~cm}^{-1}\left(\delta_{\mathrm{Si}-\mathrm{O}-}\right.$ $\mathrm{Si}$ ), as well as by the calcium carbonate main absorption bands at $1405 \mathrm{~cm}^{-1}\left(v^{\text {as }}{ }_{\mathrm{CO} 3}\right)$ and $874 \mathrm{~cm}^{-1}\left(\delta_{\mathrm{CO} 3}\right)$.

To discern the peak positions in the overlapping IR bands of collagen and tannins, the second derivatives of FTIR-ATR spectra were calculated in the spectral range of amide I and amide II $\left(1700-1450 \mathrm{~cm}^{-1}\right)$ for all the investigated samples (Fig. 5a-d). The overlapping spectral bands were assigned to the following components: amide I components centered near $1660 \mathrm{~cm}^{-1}$ and $1622-1628 \mathrm{~cm}^{-1}$, respectively; amide II band observed near $1550 \mathrm{~cm}^{-1}$; vegetable tannins bands near $1602-1605 \mathrm{~cm}^{-1}$ (visible as a shoulder of the second component of amide I) and $1502-1515 \mathrm{~cm}^{-1}$ (this band completely overlap the second component of amide II). Previously, amide I band at about $1658 \mathrm{~cm}^{-1}$ has been reported for native collagen, while the bands at $1651 \mathrm{~cm}^{-1}$ and $1633 \mathrm{~cm}^{-1}$ were correlated with denatured collagen and gelatin, respectively [55]. Similarly, the amide II components at lower wavelengths have been associated to collagen disordered structures (i.e., the band near $1530 \mathrm{~cm}^{-1}$ ) $[48,52]$ and gelatin (i.e., the band near $1518 \mathrm{~cm}^{-1}$ ) [38, 48].

As a result of the burial tests, the intensity of both amide I components decreased, suggesting a loosening of the collagen-tannin interactions (Figs. 5a-d). This destabilization process led to the dissappearance of the shoulder at $1602-1605 \mathrm{~cm}^{-1}$ after the second year, most likely due to a de-tanning process. The loosening and then breaking of collagen-tannin interactions during burial is also suported by the changes in the amide II band, namely the shift of the amide II component at $1550 \mathrm{~cm}^{-1}$ ( $\alpha$-helix) towards lower wavenumbers $\left(1546-1538 \mathrm{~cm}^{-1}\right)$ accompanied by a progressive depletion of the complex band at $1502-1515 \mathrm{~cm}^{-1}$ [38, $52,55]$. In case of $\mathrm{CH}$ leather samples, the intensity of the $1660 \mathrm{~cm}^{-1}$ component ( $\alpha$-helix) decreased while the intensity of the $1628 \mathrm{~cm}^{-1}$ component (gelatine) increased [37, 38, 40, 55]. This behaviour, explained by the unfolding of the native triple helix structure and conversion to gelatin, confirms the gelatinisation of $\mathrm{CH}$ leather revealed by the dramatic decrease of $T_{\mathrm{f}}$ evidenced through the MHT method. A similar spectral behaviour was previosly explained by Stani et al. [51] through the formation of a larger number of watermediated hydrogen bonds in denatured collagen. They assigned the component near $1630 \mathrm{~cm}^{-1}$ mainly to the carbonyl stretching of hydroxyproline and of the others amino acids involved in water mediated hydrogen bonds in the native state. Recently, some of us related the concomitant increase in intensity of amide I component at $1632 \mathrm{~cm}^{-1}$ and depletion of amide II 

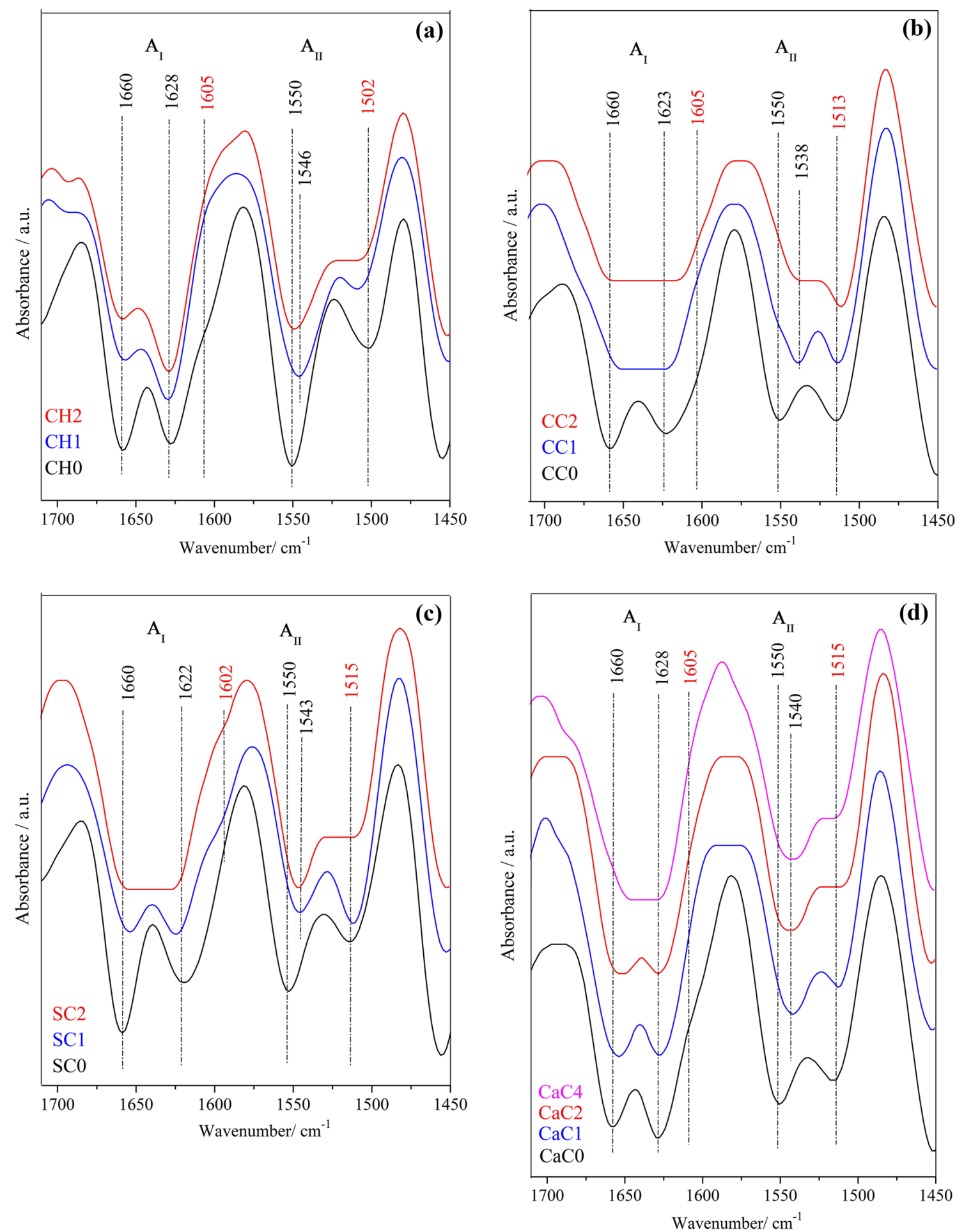

Fig. 5 The second derivative FTIR-ATR spectra in the (1700-1450) $\mathrm{cm}^{-1}$ region for $\mathbf{a} \mathrm{CH} ; \mathbf{b} \mathrm{CC} ; \mathbf{c}$ SC and $\mathbf{d} \mathrm{CaC}$, before and after soil burial tests. Figures in black reffer to collagen band's wavelengths, while figures in red reffer to tannin's bands wavelengths 
component near $1549 \mathrm{~cm}^{-1}$ to collagen gelatinisation as a result of parchment dry heating [38].

\section{Effects of burial tests on leather surface morphology by SEM}

Scanning electron microscopy (SEM) is an invasive but non-destructive high-resolution technique used for imaging a wide range of materials including the collagenous materials. Depending on magnification, changes in the surface microstructure of leather, i.e. the morphology of fibre network, fibres and microfibrils, can be observed as a result of either natural or induced deterioration [56-58].

The collagen structural damage documented by SEM imaging of both new and buried samples are illustrated in Figs. 6, 7 and 8 . The newly manufactured leather showed ordered fibrillar networking with the fibrils grouped in bundles (Fig. 6a) and their typical periodic structure cleary visible at higher magnification (Fig. 7a). The buried samples displayed discontinuities and loosening of the fibre matrix cohesion, progresive shrinkage and extended melted/gelatinised areas (Fig. 6b, c). The distorted fibrilar structure and massive presence of amourphous and gelatinised structures are already evident at higher magnification after 1-year burial period (Fig. 7b). Bozec and Odlyha [59] related the loss of the repeted periodicity of collagen fibril ultrastructure to collagen entirely structurally denaturated. This is in accordance with the DSC results presented above.

In addition, a microbial attack with the leaching of mineral component on the leather surface (most problably calcium carbonate, as indicated by FTIR-ATR results) was observed (Fig. 8). The chains of bacterial spores and filaments resemble the typical structure of some Actinomycetes [58, 60], aerobic spore forming gram-positive bacteria, which are the most abundent organism that form thread-like filaments in the soil and play a major rôle in the cycling of organic matter [61].

\section{$\mathrm{pH}$ variation as a result of the burial tests}

The $\mathrm{pH}$ value of the new vegetable tanned leathers was in the range 3.5-4.6, depending on the tannin type and manufacturing process. The $\mathrm{pH}$ values of the buried leather increased to 6.5-7.3, which is actually the $\mathrm{pH}$ value of the soil. In fact, the soil acts as a buffer, so the $\mathrm{pH}$ value of the archaeological leather does not depend on the type of damage, but on the type of soil in which it was buried. In the burial experiment we performed, the $\mathrm{pH}$ increase facilitated de-tanning of collagen-tannin matrix, thus promoting the subsequent deterioration of collagen until complete denaturation and gelatinization [18]. In addition, at $\mathrm{pH}>6$, the leaching out of vegetable
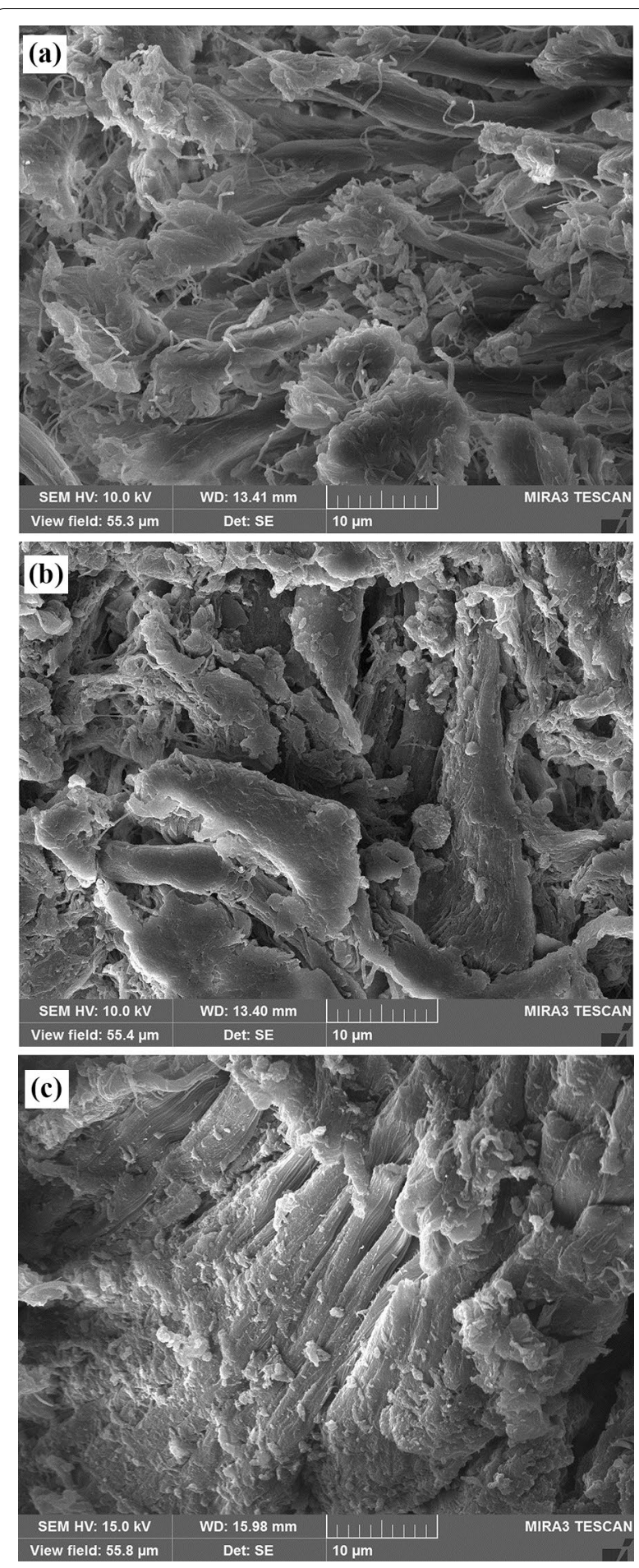

Fig. 6 SEM images showing a the ordered fibrillar networking with the fibriles grouped in bundles for $\mathrm{CaCO} ; \mathbf{b}, \mathbf{c}$ loss of the fibre matrix cohesion, progresive shrinkage and melted/gelatinised areas for $\mathrm{CaC} 1$ and $\mathrm{CaC} 2$. Magnification 5000x 

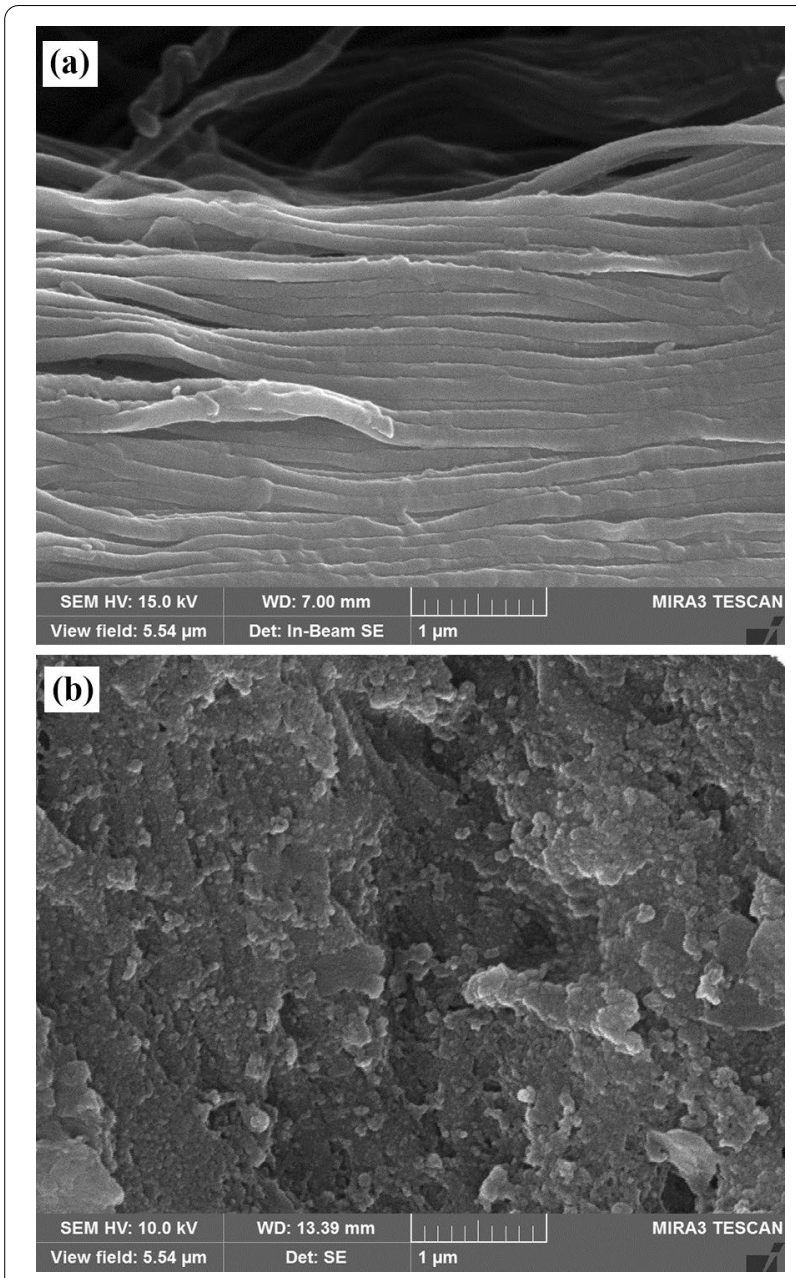

Fig. 7 SEM images showing a the typical periodic structure of the collagen fibril for $\mathrm{CaCO}$ and $\mathbf{b}$ complete loss of the surface fibrillar structure for CaC1. Magnification 50,000x

tannins is favoured. They are easily washed out by rainwater thus speeding up de-tanning process.

\section{Conclusions}

This work aimed to study the deterioration induced in vegetable leather by ground burial for 1 to 4 years. For the first time, burial tests were applied on new leather obtained from both bovine and ovine hides using both hydrolysable and condensed tannins. The analytical approach based on FTIR-ATR, DSC, TG/DTG, MHT and SEM provided clear evidences that could help understanding deterioration of archaeological leather.

The MHT method shown a general trend of increasing the structural inhomogeneity degree of collagen within the microfibres. The lengthening of $(\mathrm{A} 1+\mathrm{B} 1)$ interval was correlated with collagen pre-gelatinization and gelatin formation while de-tanning was the main cause of the (A2+B2) interval lengthening. However, it must
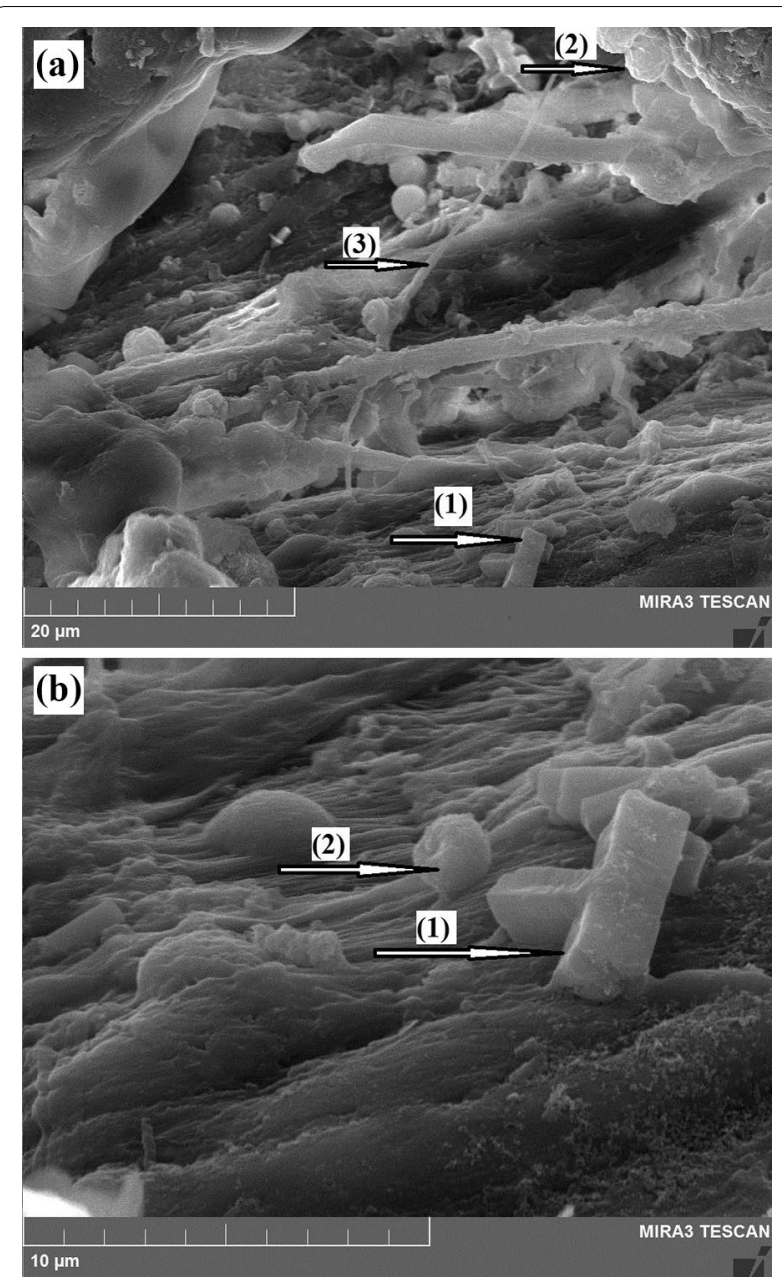

Fig. 8 SEM images of $\mathrm{CC} 1$ a at $5000 \times$ magnification and $\mathbf{b}$ at $15,000 \times$ magnification showing the presence of $\mathrm{CaCO}_{3}$ crystals (1), bacterial spores (2) and filaments (3) resembling the typical structure of Actinomycetes

be taken into account that the length of these intervals is partly due to fibre hardening/cementing through soil mineral penetration into leather porous structure. This also causes an artificial increase of $T_{\mathrm{s}}$. Hence, the use of shrinkage temperature as a metric of deterioration might be highly misleading. Noteworthy, the MHT method is still suitable for detecting pregelatinized/gelatinized collagen microfibres being thus essential for deciding the conservation interventions immediately after leather excavation. We also found that leather samples tanned with hydrolysable tannin suffered a much faster de-tanning process at the neutral $\mathrm{pH}$ of the soil, while sheep leather shown a sudden thermal destabilisation after the second year underground.

DSC analysis revealed a strong denaturing effect on collagen by the disappearance of both the denaturation peaks corresponding to the two collagen populations 
with distinct thermal stability, crystallinity and hydration degree usually detected in the temperature interval (135-240) ${ }^{\circ} \mathrm{C}$. TG/DTG results indicated the progressive reduction of cross-linking degree in the collagentannin matrix for all leather samples.

The second derivative of the FTIR-ATR leather spectra allowed us to differentiate between collagen and tannin spectral components and detect their individual shifts and relative intensity variation induced by the burial test. Thus, the de-tanning process (namely, loosening and breakdown of the collagen-tannin interactions) is indicated by the depletion of the tannin bands at $1602-1605 \mathrm{~cm}^{-1}$ and $1502-1515 \mathrm{~cm}^{-1}$, accompanid by the shift of the amide II component at $1550 \mathrm{~cm}^{-1}$ towards lower wavenumbers $\left(1546-1538 \mathrm{~cm}^{-1}\right)$. The conversion of collagen into gelatin is suggested by the decrease of $1660 \mathrm{~cm}^{-1}$ band (assigned to $\alpha$ - helical structures) and increase of the $1628 \mathrm{~cm}^{-1}$ band (assigned to gelatine).

SEM images provided useful information concerning the loosening of the fibre matrix cohesion, progresive shrinkage and formation of melted/gelatinised areas. The distorted collagen fibril ultrastructure well correlated with collagen denaturation and gelatinisation. In addition, the detection of bacterial spores and filaments revealed a microbial atack with the leaching of calcium carbonate crystals (also detected by FTIR-ATR) on leather surface.

Overall, our results confirm that damage in buried leathers follows the same main steps identified in historical leather long-term deterioration, namely leather de-tanning, collagen denaturation and gelatinisation [18]. These findings improved our understanding of the burial-induced deterioration in vegetable tanned leather and could be of great assistence in assessing archaeological leather. The analytical protocol based on MHT, DSC, FTIR-ATR and SEM demonstrated a good potential as a routine approach for a comprehensive characterization of collagen matrix structure and stability from molecular to macroscopic level. Moreover, a correct interpretation of the shrinkage activity of archaelogical leathers could offer enough information for a quick and handy characterization of leather structural stability.

\footnotetext{
Abbreviations

T:Temperature; TG: Thermal gravimetry; DTG: Differential thermal gravimetry; DSC: Differential scanning calorimetry; MHT: Micro Hot Table; FTIR: Fourier transform infrared spectroscopy; ATR: Attenuated total reflection; SEM: Scanning electron microscopy.
}

\section{Acknowledgements}

Gabriela Vyskočilová is grateful to Dr. Lucretia Miu for hosting her in the ARCH Lab of National Research \& Development Institute for Textile and Leather during her Erasmus research stage.

\section{Authors' contributions}

GV: methodology, FTIR-ATR investigation, MHT investigation, SEM investigation, TG/DTG investigation, DSC investigation, validation, writing —original draft. RS: methodology, supervision. CC: data analysis, validation, writing review and editing. EB: data analysis, validation, supervision, writing_review and editing. All authors read and approved the final manuscript.

\section{Funding}

This research received no specific grant from any funding agency in the public, commercial, or not-for-profit sectors.

\section{Availability of data and materials}

The datasets used and/or analysed during the current study are available from the corresponding author on reasonable request.

\section{Declarations}

\section{Competing interests}

The authors declare that they have no competing interests.

\section{Author details}

${ }^{1}$ Department of Chemistry, Faculty of Science, Masaryk University, Brno, Czech Republic. ${ }^{2}$ National Museum of Romanian History, Bucharest, Romania. ${ }^{3}$ Advanced Research for Cultural Heritage Group (ARCH Lab), National Research \& Development Institute for Textile and Leather, ICPI Division, Bucharest, Romania. ${ }^{4}$ Department of Chemistry, Faculty of Sciences, University of Craiova, Craiova, Romania.

Received: 16 July 2021 Accepted: 22 December 2021

Published online: 06 January 2022

\section{References}

1. Fratzl P. Collagen: structure and mechanics, an introduction. In: Fratzl P, editor. Collagen. Berlin: Springer; 2008. p. 1-13. https://doi.org/10.1007/ 978-0-387-73906-9_1.

2. Rich A, Crick FHC. The molecular structure of collagen. J Mol Biol. 1961;3:483-506.

3. Shoulders MD, Raines RT. Collagen structure and stability. Annu Rev Biochem. 2009;78:929-58.

4. Orgel JPRO, Irving TC, Wess TJ. Microfibrillar structure of type I collagen in situ. Proc Natl Acad Sci USA. 2006;103:9001-5.

5. Persikov AV, Ramshaw JA, Brodsky B. Prediction of collagen stability from amino acid sequence. J Biol Chem. 2005;280:19343-9.

6. Buehler MJ. Nature designs tough collagen: explaining the nanostructure of collagen fibrils. Proc Natl Acad Sci USA. 2006;103:12285-90.

7. Covington AD. Modern tanning chemistry. Chem Soc Rev. 1997;26:111-26.

8. Covington AD. Tanning chemistry: the science of leather. In: Wise W, Covington AD, editors. Cambridge: The Royal Society of Chemistry; 2019.

9. Schröpfer M, Meyer M. Investigations towards the binding mechanisms of vegetable tanning agents to collagen. Res J Phytochem. 2016;10(2):58-66. https://doi.org/10.3923/rjphyto.2016.58.6.

10. Covington AD, Song L, Suparno O, Koon H, Collins MJ. Link-lock: an explanation of the chemical stabilisation of collagen. J Soc Leather Technol Chem. 2008:92:1-7.

11. Newton C, Cook C. Caring for archaeological collections. Preventive conservation guidelines for collections. Government of Canada, Canadian Conservation Institute. https://www.canada.ca/en/conservation-insti tute/services/preventive-conservation/guidelines-collections.html.

12. Spangenberg JE, Ferrer M, Tschudin P, Volken M, Hafner A. Microstructural, chemical and isotopic evidence for the origin of late neolithic leather recovered from an ice field in the Swiss Alps. J Archaeol Sci. 2010;37(8):1851-65. https://doi.org/10.1016/j.jas.2010.02.003.

13. Ebsen JA, Haase K, Larsen R, Poulsen Sommer DV, Ørsted BL. Identifying archaeological leather-discussing the potential of grain pattern analysis and zooarchaeology by mass spectrometry (ZooMS) through a case study involving medieval shoe parts from Denmark. J Cult Herit. 2019;39:21-31. https://doi.org/10.1016/j.culher.2019.04.008. 
14. Plavan V, Miu L, Gavrilyuk N. Evaluation of the amino acid composition, structure and properties of archaeological leather. Procedia Chem. 2013;8:279-83. https://doi.org/10.1016/j.proche.2013.03.034.

15. Koochakzaei A, Achachluei MM. Red stains on archaeological leather: degradation characteristics of a shoe from the 11th-13th centuries (Seljuk period, Iran). J Am Inst Conserv. 2015;54(1):45-56. https://doi.org/ 10.1179/1945233014Y.0000000033.

16. Hassan RRA. A preliminary study on using linseed oil emulsion in dressing archaeological leather. J Cult Herit. 2016;21:786-95.

17. Budrugeac P, Carsote C, Miu L. Application of thermal analysis methods for damage assessment of leather in an old military coat belonging to the History Museum of Braşov-Romania. J Therm Anal Calorim. 2017;127(1):765-72. https://doi.org/10.1007/s10973-016-5343-8.

18. Carsote C, Badea E. Micro differential scanning calorimetry and Micro Hot Table method for quantifying deterioration of historical leather. Herit Sci. 2019;7(48):1-13. https://doi.org/10.1186/s40494-019-0292-8.

19. Carsote C, Badea E, Caniola I, Paunescu S, Lupas MC, Sendrea C, Miu L. The Homiliary of Varlaam: scientific investigation of the leather bookbinding. Rev Chim. 2020;71(3):51-8. https://doi.org/10.37358/RC.20.3.7973.

20. Proietti N, Di Tullio V, Carsote C, Badea E. ${ }^{13} \mathrm{C}$ solid-state NMR complemented by ATR-FTIR and micro-DSC to study modern collagen-based material and historical leather. Magn Reson Chem. 2020;58:840-59. https://doi.org/10.1002/mrc.5024.

21. Geoportal. The Czech National Geoportal. 2019. https://geoportal.gov.cz/ web/guest/map?permalink=3ce4d8ab3c6bclee95a090c4f411668f.

22. CHMI. Czech Hydrometeorological Institute. 2020. http://portal.chmi.cz/ historicka-data/pocasi/uzemni-srazky?!=en.

23. Budrugeac $P, C$ Cucos A, Miu L. The use of thermal analysis methods for authentication and conservation state determination of historical and/ or cultural objects manufactured from leather. J Therm Anal Calorim. 2011:104:439-50

24. ISO, Č., ČSN ISO 10390: soil quality—determination of pH. Český normalizační institut. 2011. p. 12

25. Badea E, Şendrea C, Carsote C, Adams A, Blümich B, lovu H. Unilateral NMR and thermal microscopy studies of vegetable tanned leather. exposed to dehydrothermal treatment and light irradiation. Microchem J. 2016;129:158-65. https://doi.org/10.1016/.microc.2016.06.013.

26. Sebestyén Z, Jakab E, Badea E, Barta-Rajnai E, Şendrea C, Czégény Z. Thermal degradation study of vegetable tannins and vegetable tanned leathers. J Anal Appl Pyrol. 2019;138:178-87. https://doi.org/10.1016/j. jaap.2018.12.022.

27. Chahine $\mathrm{C}$. Changes in hydrothermal stability of leather and parchment with deterioration: a DSC study. Thermochim Acta. 2000;365:101-10.

28. Larsen R, Vest M, Nielsen K. Determination of hydrothermal stability (shrinkage temperature) of historical leathers by Micro Hot Table technique. J Soc Leather Technol Chem. 1993;77:151-6.

29. Larsen R, Vest M, Nielsen K. Determination of hydrothermal stability. In: Larsen R, Vest M, Kejser UB, editors. STEP Leather Project. Evaluation of the correlation between natural and artificial ageing of vegetable tanned leather and determination of parameters for standardization of an artificial ageing method. Copenhagen: Bjarnholt Repro; 1994. p. 151-64.

30. Larsen R, Poulsen Sommer DV, Mühlen AK. Scientifc approach in conservation and restoration of leather and parchments objects in archives and libraries. In: Engel P, editor. New approaches to book and paper conservation-restoration. Wien: Verlag Berger; 2011. p. 239-58.

31. Larsen R. Experiments and observations in the study of environmental impact on historical vegetable tanned leathers. Thermochim Acta. 2000:365:85-99.

32. Carsote C, Kövari L, Albu C, Hadîmbu E, Badea E, Miu L, Dumitrescu G. Bindings of rare books from the collections of the Romanian Academy Library - a multidisciplinary study. Leather Footwear J. 2018;18(4):307-20.

33. Badea E, Poulsen Sommer DV, Muhlen Axelsson K, Larsen R, Kurysheva A, Miu L, Della Gatta G. Damage ranking of historic pachments: from microscopic studies of fibre structure to collagen denaturation assessment by micro DSC. e-Preserv Sci. 2012;9:97-109.

34. Vyskočilová G, Ebersbach M, Kopecká R, Prokeš L, Príhoda J. Model study of the leather degradation by oxidation and hydrolysis. Herit Sci. 2019;7:1-13. https://doi.org/10.1186/s40494-019-0269-7.

35. Badea E, Carsote C, Hadimbu E, Sendrea C, Lupas MC. The effect of halloysite nanotubes dispersions on vegetable-tanned leather thermal stability. Herit Sci. 2019;7:68. https://doi.org/10.1186/s40494-019-0310-x.
36. Sendrea C, Carsote C, Radu M, Badea E, Miu L. The effect of gamma irradiation on shrinkage activity of collagen in vegetable tanned leather. Rev Chim. 2017;68:1535-8. https://doi.org/10.37358/rc.17.7.5711.

37. Cappa F, Paganoni I, Carsote C, Badea E, Schreiner M. Studies on the effects of mixed light-thermal ageing on parchment by vibrational spectroscopy and micro hot table method. Herit Sci. 2020;8(15):1-12. https:// doi.org/10.1186/s40494-020-0353-z.

38. Cappa F, Paganoni I, Carsote C, Schreiner M, Badea E. Studies on the effect of dry-heat ageing on parchment deterioration by vibrational spectroscopy and micro hot table method. Polym Degrad Stab. 2020;182(109375):1-11. https://doi.org/10.1016/j.polymdegradstab.2020. 109375.

39. Carsote C, Badea E, Miu L, Della GG. Study of the effect of tannins and animal species on the thermal stability of vegetable leather by differential scanning calorimetry. JTherm Anal Calorim. 2016;124:1255-66. https:// doi.org/10.1007/s10973-016-5344-7.

40. Carsote C, Şendrea C, Micu MC, Adams A, Badea E. Micro-DSC, FTIR-ATR and NMR MOUSE study of the dose-dependent effects of gamma irradiation on vegetable-tanned leather: the influence of leather thermal stability. Radiat Phys Chem. 2021;189:109712. https://doi.org/10.1016/j. radphyschem.2021.109712.

41. Miles CA, Ghelashvili M. Polymer-in-a-Box Mechanism for the thermal stabilization of collagen molecules in fibers. Biophys J. 1999;78(6):3243-52.

42. Samouillan V, Delaunay F, Dandurand J, Merbahi N, Gardou JP, Yousfi M, Gandaglia A, Spina M, Lacabanne CJ. The use of thermal techniques for the characterization and selection of natural biomaterials. Funct Biomater. 2011;2:230-48. https://doi.org/10.3390/jfb2030230.

43. Popescu C, Budrugeac P, Miu L, Wortmann FJ, Demco DE, Baias M. Assessment of collagen-based materials which are supports of cultural and historical objects. Polym Degrad Stabil. 2008;93(5):976-82.

44. Budrugeac P, Badea E, Della Gatta G, Miu L, Comanescu A. A DSC study of deterioration caused by environmenthal chemical pollutants to parchment, a collagen-based material. Thermochim Acta. 2010;500:51-62.

45. Badea E, Usacheva T, Della GG. The use of differential scanning calorimetry to characterise collagen deterioration in parchment. Russ Chem J. 2015;59(1):28-41.

46. Doyle BB, Bendit EG, Blout ER. Infrared spectroscopy of collagen and collagen-like polypeptides. Biopolymers. 1975;14:937-57. https://doi.org/ 10.1002/bip.1975.360140505.

47. Payne KJ, Veis A. Fourier transform IR spectroscopy of collagen and gelatin solutions: deconvolution of the amide I band for conformational studies. Biopolymers. 1988;27:1749-60. https://doi.org/10.1002/bip.36027 1105.

48. Barth A. Infrared spectroscopy of proteins. Biochim Biophys Acta Bioenerg. 2007;1767:1073-101. https://doi.org/10.1016/j.bbabio.2007.06.004.

49. De Campos VB, Mello MLS. Collagen type I amide I band infrared spectroscopy. Micron. 2011;42:283-9. https://doi.org/10.1016/j.micron.2010. 09.010 .

50. Glassford SE, Byrne B, Kazarian SG. Recent applications of ATR-FTIR spectroscopy and imaging to proteins. Biochim Biophys Acta. 2013;1834:2849-58.

51. Stani C, Vaccari L, Mitri E, Birarda G. FTIR investigation of the secondary structure of type I collagen: new insight into the amide III band. Spectrochim Acta A Mol Biomol Spectrosc. 2020;229:118006.

52. Vichi A, Eliazyan G, Kazarian SG. Study of the degradation and conservation of historical leather book covers with Macro Attenuated Total Reflection-Fourier Transform Infrared Spectroscopic Imaging. ACS Omega. 2018;3:7150-7.

53. Falcão L, Araújo MEM. Tannins characterization in historic leathers by complementary analytical techniques ATR-FTIR, UV-Vis and chemical tests. J Cult Herit. 2013;14:499-508.

54. Falcão L, Araújo MEM. Vegetable tannins used in the manufacture of historic leathers. Molecules. 2018;23:8-10. https://doi.org/10.3390/molec ules23051081.

55. Rabotyagova OS, Cebe P, Kaplan DL. Collagen structural hierarchy and susceptibility to degradation by ultraviolet radiation. Mater Sci Eng C. 2008;28:1420-9. https://doi.org/10.1016/j.msec.2008.03.012.

56. Bicchieri M, Biocca P, Colaizzi P, Pinzari F. Microscopic observations of paper and parchment: the archaeology of small objects. Herit Sci. 2019;7(47):1-12. https://doi.org/10.1186/s40494-019-0291-9. 
57. Vadrucci M, Cicero C, Parisse P, Casalis L, De Bellis G. Surface evaluation of the effect of X-rays irradiation on parchment artefacts through AFM and SEM. App Surf Sci. 2020;513:145881. https://doi.org/10.1016/j.apsusc. 2020.145881 .

58. Piñar G, Sterflinger K, Pinzari F. Unmasking the measles-like parchment discoloration: molecular and microanalytical approach. Environ Microbiol. 2015:17(2):427-43. https://doi.org/10.1111/1462-2920.12471.

59. Bozec L, Odlyha M. Thermal denaturation studies of collagen by microthermal analysis and atomic force microscopy. Biophys J. 2011;101:228-36.

60. Pinzari F, Gutarowska B. Extreme colonizers and rapid profiteers: the challenging world of microorganisms that attack paper and parchment. In: Joseph E, editor. Microorganisms in the deterioration and preservation of cultural heritage. Berlin: Springer; 2021. https://doi.org/10.1007/ 978-3-030-69411-1_4.

61. Bhatti AA, Haq S, Bhat RA. Actinomycetes benefaction role in soil and plant health. Microb Pathog. 2017;111:458-67. https://doi.org/10.1016/j. micpath.2017.09.036.

\section{Publisher's Note}

Springer Nature remains neutral with regard to jurisdictional claims in published maps and institutional affiliations.

\section{Submit your manuscript to a SpringerOpen ${ }^{\circ}$ journal and benefit from:}

- Convenient online submission

- Rigorous peer review

- Open access: articles freely available online

- High visibility within the field

- Retaining the copyright to your article

Submit your next manuscript at $\boldsymbol{\nabla}$ springeropen.com 